[accepted for publication in In Áine McMurtry and Deborah Pinfold, eds Austria in Transit, a special issue of Austrian Studies, forthcoming 2019].

\title{
Dialogicity, Monologicity and the Crisis of Hospitality in Elfriede Jelinek's Die
}

\section{Schutzbefohlenen}

JANE WILKINSON

\section{Edinburgh Napier University}

\begin{abstract}
I
wem dürfen wir ihn bitte überreichen, diesen Stapel, wir haben zwei Tonnen Papier beschrieben, man hat uns natürlich dabei geholfen, bittend halten wir es nun hoch, das Papier, nein, Papiere haben wir nicht, nur Papier, wem dürfen wir es übergeben? Ihnen? Bitte, hier haben Sie es, aber wenn Sie nichts damit anfangen, müssen wir das alles noch einmal kopieren, noch einmal ausdrucken, das ist Ihnen doch klar? ${ }^{1}$
\end{abstract}

[Whom may we hand this, this pile, we filled two tons of paper with our writing, we had help with that, of course, now we hold it up suppliantly, all that paper, no we don't have papers, only paper, to whom may we give it? You? Please, here it is, but if you do nothing with it, we have to make another copy, print it all again, surely you are aware of that? $]^{2}$

\footnotetext{
${ }^{1}$ Elfriede Jelinek, Die Schutzbefohlenen (Reinbek, 2013), p. 2. Subsequent references will be provided in text with the abbreviation $S b$ and the page number.

${ }^{2}$ Elfriede Jelinek, Charges (The Supplicants), trans. by Gitta Honegger (London, New York, Calcutta, 2016), p. 1. Subsequent references are provided in text as Charges and the page number. Unless indicated otherwise, all English translations of quotations from the play are
} 
These lines from early in her play Die Schutzbefohlenen [Charges], ${ }^{3}$ encapsulate in both content and form Elfriede Jelinek's aesthetic and critical engagement with responses to the so-called 'refugee crisis' in Austria and the European Union, as well as with questions of hospitality and its political and ethical implications more broadly. Specifically, Jelinek draws attention to the apparent incompatibility of unconditional hospitality as the ethical, humane response to the stranger in need and the various forms of conditional hospitality determined by politics and self-interest, and enshrined in the laws of individual states; an incompatibility interrogated by Jacques Derrida and Emmanuel Levinas in their own philosophies of hospitality and welcome. ${ }^{4}$ In Jelinek's play text we are immediately confronted by what Silke

taken from this published translation. The published English translation does not always correspond directly to the German. In some places, certain details in the original German text are omitted from the English translation. Where the omitted sections or details are relevant to the point being made in relation to the quotation, I supplement the English quotation and note this in a footnote.

${ }^{3}$ Charges is the title of Gitta Honegger's translation. The German title Die Schutzbefohlenen is used throughout to refer to the play text.

${ }^{4}$ Jacques Derrida, 'Hostipitality', Angelaki. Journal of the Theoretical Humanities, 5.3 (2000), 3-18; Jacques Derrida, On Cosmopolitanism and Forgiveness, trans. by Mark Dooley and Michael Hughes (London, 2001); Jacques Derrida, 'The Principle of Hospitality', Parallax 11.1 (2005), 6-9; Jacques Derrida and Anne Dufourmantelle, Of Hospitality. Anne Dufourmantelle Invites Jacques Derrida to Respond, trans. by Rachel Bowlby (Stanford, CA, 2000); Emmanuel Levinas, Ethics and Infinity, trans. by R.A. Cohen (Pittsburgh, PA, 1985). 
Felber calls 'an undefined and irritating first person plural.'5 This 'wir' [we] features throughout, representing different and often conflicting perspectives on migration, borders, asylum and belonging: those of migrants and refugees seeking sanctuary in Austria and other EU countries, of the authorities processing their applications, of 'ordinary' citizens in Austria and beyond, and of the media. Here, the 'wir' is attributable to the migrants and refugees who, on arrival in the EU, face an unwelcoming and impenetrable maze of bureaucracy and form filling. Jelinek's playful repetition of the word 'Papier(e)' [paper(s)] neatly highlights the cruel ironies inherent in an immigration and asylum system in which documents take precedence over both human lives and individual stories and identities. The fact that these individual stories and identities are repeatedly subsumed by the collective 'wir' throughout the text only serves to underline the de-individualisation of migrants and refugees by the authorities, legal systems, media and populations of 'receiving' countries. In this extract, those representing the 'receiving' countries constitute the equally unspecific 'Sie' ['you'] whom the refugee voices repeatedly attempt to engage in dialogue, seeking help in a series of pleas and questions. As these remain unanswered on page or stage, the readers and audience become implicated in the asylum application processes referenced and are compelled to react. Moreover, the refugee voices appear to respond to questions posed or pre-empted, but we neither read nor hear the voices of interlocutors. This is a pattern followed throughout the play text: we encounter only one side of a conversation and we read reports of conversations without being privy to actual dialogues.

\footnotetext{
${ }^{5}$ Silke Felber, '(Un)making Boundaries. Representing Elfriede Jelinek's Charges (The Supplicants)', Critical Stages /Scènes Critiques, 14 (2016), p. 4.
} 
Although there is evidence of what Nicholas O'Pagan terms a 'pull towards dialogue or the dialogical'6 in the pleas, questions and responses, the lack of 'conventional' interaction between voices or speakers means that Die Schutzbefohlenen is, in quite significant ways, monologic. Indeed, according to Steve Wilmer, it 'reads like a long, rambling monologue'.7 In this, it is emblematic of Jelinek's 'postdramatic' writing for the theatre which, to borrow Karen Jürs-Munby's definition, ‘tends to lack dramatic plot, psychological characters and often the form of a dialogue or even indicated speakers.' As Maja Sibylle Pflüger maintains, many of Jelinek's theatre texts closely resemble monologues because the speakers are always in 'isolation'. ${ }^{9}$ Even when apparently speaking to somebody else, they do not relate to their interlocutors but remain 'in ihren Reden befangen' [imprisoned in their own speeches], speaking 'aneinander vorbei' [past each other] and presenting their own view of things. ${ }^{10}$ As Pflüger and others argue, Jelinek's theatre texts are, therefore, 'dialogic' in the sense that they engage with a variety of perspectives, but 'monologic' insofar as the voices articulating those

${ }^{6}$ Nicholas O’Pagan, 'Inside Fateh Azzam's Baggage: Monologue and Forced Migration', Theatre Research International, 32 (2010), 16-31 (p. 19).

${ }^{7}$ Steve Wilmer, 'Cultural Encounters in Modern Productions of Greek Tragedy.' Nordic Theatre Studies, 28.1 (2016), 15-26 (p. 20).

${ }^{8}$ Karen Jürs-Munby, 'The Resistant Text in Postdramatic Theatre: Performing Elfriede Jelinek’s Sprachflächen', Performance Research 14.1 (London, 2009), 46-57 (p. 48).

${ }^{9}$ Maja Sybille Pflüger, Vom Dialog zur Dialogizität. Die Theaterästhetik von Elfriede Jelinek (Tübingen \& Basel, 1996), p. 27.

10 Ibid., p. 22-23. 
perspectives do not engage in interaction. ${ }^{11}$ This 'monologized dialogue' or 'dialogized monologue' is used by Jelinek across her postdramatic oeuvre to represent breakdowns in or even the impossibility of communication. As successful communication is so fundamental to the creation and maintenance of a hospitable society, I argue here that Jelinek's postdramatic form is ideally suited to illustrating the failures of hospitality in Austria, the EU and the wider world in recent years. By focussing on instances in the text where dialogue is sought or alluded to but fails, and where voices representing different perspectives vie for attention, I propose that it effectively presents the so-called refugee or migration crisis as a 'crisis of hospitality' in which traditional understandings and practices of hospitality are no longer viable and only certain, privileged voices can be heard above the cacophony of noise around the topic.

Jelinek's aesthetic and critical engagement with hospitality in Die Schutzbefohlenen is the subject of a growing body of research. Several studies focus on her rewriting of Aeschylus' tragedy Hiketides (Die Schutzflehenden; The Suppliants / The Suppliant Women) as a means of interrogating the principles and practices of hospitality in twenty-first century Austria and Europe. Steve Wilmer, Silke Felber and Luigi Reitani argue that Jelinek's postdramatic

11 Ulrike Haß, 'Theaterästhetik: Theaterformen', in Jelinek Handbuch, ed. by Pia Janke (Stuttgart, 2013), pp. 62-67; Monika Meister, 'Bezüge zur Theatertradition', in Jelinek Handbuch, ed. by Pia Janke (Stuttgart, 2013), pp. 68-73. 
rendering of this 'traditional' drama about clearly defined laws and notions of hospitality in Ancient Greece shines a light on the dismantling of these laws and notions today. ${ }^{12}$ The Ancient Greek principle of xenia was based on reciprocity between 'host' and 'guest': guests, even strangers, had to be welcomed, sheltered and fed without question or condition, but were in turn expected to be polite and respectful to their hosts, and to offer gifts. Accordingly, the suppliant women of Aeschylus' play - the fifty daughters of Danaus - are welcomed into the Greek kingdom of Argos after fleeing the threat of forced marriage to their cousins in Egypt; and this despite the risk of instigating war. The play's classical form allows for unity of action, place and time, for clearly defined roles and designated speakers, as well as for dialogue between 'guests' and 'hosts': it lends itself to the representation of xenia. Taking this play as a point of departure only (Die Schutzbefohlenen bears strikingly little resemblance to Die Schutzflehenden, despite clear intertextual references and a direct acknowledgement at the end), Jelinek breaks down these classical unities to create a text without acts, scenes, named characters or even designated speakers in which hospitality and the relationships and dialogues it depends on have also broken down. Felber and Kovacs describe the result as 'schwärmendes Schreiben' [swarming writing]: an unbroken flow of

12 Wilmer, 'Cultural Encounters'; Steve Wilmer, 'Greek Tragedy as a Window on the Dispossessed', New Theatre Quarterly, 33.3 (2017), 277-87; Felber, 'Unmaking Boundaries'; Silke Felber, 'Wer wenn nicht wir? Zur Kontingenz europäischer Zugehörigkeit bei Aischylos und Elfriede Jelinek', in Vorstellung Europa Performing Europe. Interdisziplinäre Perspektiven auf Europa im Theater der Gegenwart, ed. by Natalie Bloch, Dieter Heimböckel and Elisabeth Tropper (Berlin, 2017), pp. 43-55; Luigi Reitani, 'Daß uns Recht geschieht, darum beten wir. Elfriede Jelineks Die Schutzbefohlenen', in JELINEK[JAHR]BUCH 2014-2015 (Vienna, 2015), pp. 55-71. 
text which serves to illustrate both the negative media portrayals of 'swarms' of migrants and refugees arriving in Europe, and the dissolution of the presupposed boundary between 'inside' and 'outside', 'us' and 'them', and - by extension - 'host' and 'guest'. ${ }^{13}$ This postdramatic textual form reflects a world in which the social structures, norms and relationships that form the basis of acts of hospitality have been shaken.

In several essays, Felber links this 'schwärmendes Schreiben' to the deliberately ambiguous subject position of the text. In the absence of named characters or even designated speakers we are left with a constantly shifting first-person plural. ${ }^{14}$ Luigi Reitani similarly highlights the text's polyphony, but suggests that even antagonistic and xenophobic views are mediated through the voices of the refugee chorus that speaks at the start. He maintains that the refugee voices articulate their identities and positions at least partly in response to what others say about them - they perform the images of themselves they see reflected in the mirror society holds up to them. ${ }^{15}$ Reitani thereby draws, albeit inexplic itly, on Homi K. Bhabha's concept of mimicry in colonial and postcolonial contexts: the refugees mimic the attitudes, views and even words of the inhospitable host, he argues, in order to defend themselves against the xenophobia expressed therein. ${ }^{16} \mathrm{He}$ further argues that, although dialogically engaged with a range of 'Gegenstimmen' [opposing voices], unlike Aeschlyus'

${ }^{13}$ Silke Felber and Teresa Kovacs, 'Schwarm und Schwelle. Migrationsbewegungen in Elfriede Jelineks Die Schutzbefohlenen',TRANSIT. A Journal of Travel, Migration and Multiculturalism in the German-speaking World,10.1 (2015), 1. See also Felber '(Un)making Boundaries', p. 9.

14 See footnote 5 .

${ }^{15}$ Reitani, 'Daß uns recht geschieht', p. 64

${ }^{16}$ Homi K. Bhabha, The Location of Culture (London, 1994). 
daughters of Danaus, the refugee voices in Die Schutzbefohlenen find nobody to listen to them and are consequently 'aus dem Gesellschaftsvertrag ausgeschlossen' [excluded from the social contract].${ }^{17}$ I build on both parts of Reitani's argument to suggest that the mimicking of external critical voices serves to highlight the lack of dialogue and therefore the inhospitality faced by migrants and refugees. We neither see nor hear 'others' responding to them but rather hear reports and appropriations of those responses.

In his examination of the polyphonic form of Die Schutzbefohlenen, Kyung-ho Cha argues that Jelinek's play is first and foremost about the impossibility of telling traumatic stories and therefore the incommunicability of the refugee experience. ${ }^{18}$ He suggests that the 'traumatized speech' of the play text, encapsulated in the restless, broken syntax, functions as a critical comment on the ways in which these stories are packaged and presented in a consumable way by the mass media in order to evoke sympathy. His argument can therefore be seen as part of the wider debate around the ethics of representation and appropriate forms of theatrical response to the so-called 'refugee crisis'. Both Katrin Sieg and Jonas Tinius have recently criticized the predominance in repertoires of semi-autobiographical documentary plays purporting to tell 'authentic' stories of migration based on interviews and ethnographic research involving migrants and refugees. ${ }^{19}$ They are concerned that plays such as Asylum

${ }^{17}$ Reitani, 'Daß uns recht geschieht', p. 64

${ }^{18}$ Kyung-ho Cha, 'Die literarische Darstellung der Flüchtlinge und die Kritik des medialen Menschenrechtsdiskurses in Elfriede Jelineks Die Schutzbefohlenen', Mitteilungen des Deutschen Germanistenverbandes, 63.4 (2016), 358-69.

${ }^{19}$ Katrin Sieg, 'Refugees in German Documentary Theatre', Critical Stages / Scènes Critiques, 14 (2016); Jonas Tinius, 'Authenticity and Otherness. Reflecting Statelessness in German Postmigrant Theatre', Critical Stages /Scènes Critiques, 14 (2016). 
Monologues (2013), written and directed by Michael Ruf of the Bühne für Menschenrechte [Stage for Human Rights], and Letters Home (2014), created and performed by a group of refugees working together with social workers (The Refugee Club Impulse), exploit and perpetuate the narrative of 'crisis' and contribute to the further 'othering' of refugees by telling simplified and often stereotypical stories selected and edited by the author or director to appeal to audiences' emotions. They are also critical of the first-person monologic form of the plays which, Sieg argues, 'contributes to the conflation of actor and role. ${ }^{20}$ As an alternative to documentary theatre with its 'ostentatious lack of dramatic artifice', Sieg prefers 'more self-reflective and "playwriterly" text[s],' where the dramatist's creativity is evident in language, structure and intertextuality, and readers and audiences are encouraged to engage thoughtfully and critically, rather than respond instinctively and emotionally. ${ }^{21}$ This mirrors Jelinek's own views on the theatre. As Karen Jürs-Munby explains, she opposes traditional mimetic theatre aesthetics and wants her 'recipients' to be challenged. ${ }^{22}$ In relation to Die Schutzbefohlenen, Felber and Kovacs argue that the form of the play - 'die Produktion eines endlos anmutenden Textflusses' [the production of an apparently endless flow of text] 'eine regelrechte Überforderung der RezipientInnen provoziert' [places excess demands on recipients]. ${ }^{23}$

I argue that Jelinek's postdramatic form not only represents the incommunicability of the refugee experience but also foregrounds the challenges of communication for all affected by the so-called 'crisis'. I focus on the absence of conventional dialogue within a text

\footnotetext{
${ }^{20}$ Sieg, 'Refugees in German Documentary Theatre', p. 5.

${ }^{21}$ Ibid., p. 11.

22 Jürs-Munby, 'The Resistant Text', p. 48

${ }^{23}$ Felber and Kovacs, 'Schwarm und Schwelle', pp. 8-9.
} 
featuring multiple voices and reflect on how this facilitates a critique of the ethics, laws and processes of hospitality in Austria, Europe and beyond. In doing so, I draw on Jacques Derrida's extensive work on hospitality and on the tension he outlines between universal human rights, according to which everyone should be entitled to unquestioning hospitality the bedrock of a humane and just society - and the political reality of a world divided into sovereign states with their own laws and politics of selective welcome. ${ }^{24}$ This tension has been particularly evident in political reactions to and narratives surrounding the 'refugee crisis' in Europe in recent years. As argued by Emma Cox and Marilena Zaroulia: 'Europe is caught at a crossroads, maintaining a narrative of liberal, human rights-driven hospitality while fostering a reactionary crisis management, which dictates policies both inside and outside the EU. ${ }^{25}$ They echo others such as Anika Marschall and Katrin Sieg who maintain that the discourse of 'crisis' is problematic and potentially damaging because it connotes an emergency requiring urgent resolution and positions the refugees as both cause and subject of the 'problem'. ${ }^{26}$ The arrival of migrants and refugees in the EU, a protected 'gated

${ }^{24}$ Specifically, my thinking is informed by: Derrida and Dufourmantelle, Of Hospitality; Derrida, On Cosmopolitanism; Derrida, 'The Principle of Hospitality.

${ }^{25}$ Emma Cox and Marilena Zaroulia, 'Mare Nostrum, or On Water Matters', Performance Research 21.2 (2016), 141-49, p. 142.

${ }^{26}$ Anika Marschall, 'What can Theatre do about the Refugee Crisis? Enacting Commitment and Navigating Complicity in Performative Interventions', Research in Drama Education. The Journal of Applied Theatre and Performance, 23.2 (2018), 148-66; Sieg, 'Refugees in German Documentary Theatre'. 
community' to borrow Henk van Houtum and Roos Pijpers' apt metaphor, ${ }^{27}$ has put the politicians and populations of member states into a state of panic as they work out how to respond. They are the ones declaring the crisis. I therefore agree with Anika Marschall's assertion that the 'so-called refugee crisis [...] could be more properly defined as a humanitarian crisis in which many refugees, migrants and racialized groups have to face unjust asylum laws and perilous nationalistic politics in Europe' 28 and suggest that the 'humanitarian crisis' might be understood specifically as a 'crisis of hospitality' in which our individual, societal and institutional responses to the 'other' in need are challenged.

III

The crisis of hospitality created by the tension between human rights and politics clearly emerges in Die Schutzbefohlenen through Jelinek's exposé of the selective politics and practices of hospitality in Austria and the EU. As outlined by, among others, Bärbel Lücke and Luigi Reitani, Jelinek draws on a number of controversial cases which received considerable attention in the Austrian and international media to shine a critical light on the sharply contrasting experiences of refugees and 'desirable' migrants perceived to be of high

${ }^{27}$ Henk van Houtum and Roos Pijpers, 'The European Community as a Gated Community. Between Security and Selective Access', in EU Enlargement, Region Building and Shifting Borders of Inclusion and Exclusion, ed. by James Wesley Scott (Aldershot, 2006), pp. 3-13. ${ }^{28}$ Marschall, 'What can Theatre do about the Refugee Crisis?', p. 149. 
value to the country. ${ }^{29}$ Specifically, she juxtaposes the Refugee Protest Camp Vienna staged by migrants, refugees and supporting activists in 2012-13 against the cases of two Russian 'celebrities' fast-tracked to Austrian citizenship because of the benefits they were perceived to bring the country: so-called 'Blitz-Eingebürgerte' [citizens naturalized at lightning speed]. While those involved in the Refugee Protest Camp found that their attempts to highlight the inhospitality of both the inhumane living conditions in the national reception centre in Traiskirchen and the handling of asylum cases were quickly shut down, Tatyana Yumasheva, daughter of the former Russian president Boris Yeltsin, and Anna Netrebko, world-renowned opera singer, were barely required to say a word in support of their own applications for Austrian citizenship - the pinnacle of state hospitality - in 2009 and 2006 respectively. ${ }^{30} \mathrm{I}$ argue that the dialogic-monologic form of Die Schutzbefohlenen allows Jelinek to foreground

${ }^{29}$ Bärbel Lücke, Zur Ästhetik von Aktualität und Serialität in den Addenda-Stücken Elfriede Jelineks zu Die Kontrakte des Kaufmanns, Über Tiere, Kein Licht, Die Schutzbefohlenen (Vienna, 2017); Reitani, 'Daß uns Recht geschieht'.

${ }^{30}$ For a comprehensive account and analysis of the Refugee Protest Camp Vienna, see: Ilke Ataç, 'Refugee Protest Camp: Making Citizens through the Locations of the Protest Movement', Citizenship Studies, 20.5 (2016), 629-46. For reports on the BlitzEinbürgerungen [naturalisations at lightning speed] see: Kurt Kuch, 'Blitz-Einbürgerung. Tatjana Yumaschewa bekam Staatsbürgerschaft nach massiver Intervention von Magna', News, 24 April 2013, https://www.news.at/a/jelzin-tochter-blitz-einbuergerung-oesterreich [accessed 20 January 2019]; 'Anna Netrebko wird eingebürgert', Der Standard, 25 July 2006, https://derstandard.at/2528743/Anna-Netrebko-w ird-e ingebuergert [accessed 20 January 2019]. 
that different 'types' or 'categories' of migrants enjoy different levels of access to and representation in the dialogue which is so fundamental to hospitality.

This article's opening quotation is but one of multiple instances throughout the play where the voices attributable to the refugees speak 'in isolation', ${ }^{31}$ receiving neither help nor response to questions posed. In another repeated example, the refugee voices challenge the impossible requirement to provide evidence for everything - identity, reasons for leaving their home country, eligibility for asylum - by referring to video footage of the execution of their family members which has been rejected by the authorities as sufficient evidence for their asylum claim: 'hier können Sie sehen, den Beweis sehen, auf diesem Video, wie zwei Männern die Köpfe abgeschnitten werden, ist das nicht furchtbar? Sie glauben nicht, daß das meine Cousins sind? Ich habe Zeugen. Sie glauben es nicht. Aber sehen können Sie es, Sie sehen es hier' ( $S b$ 6) [here you can see it, see the proof, in this video, how two men are getting their heads cut off, isn't that horrifying? You don't believe that they are my cousins? I have witnesses. You don't believe it, but you can see it, you see it right there] (Charges 56). ${ }^{32}$

The receiving country's insistence on evidence is a key part of what Derrida describes as 'choosing, electing, filtering, selecting their invitees, visitors, or guests, those to whom they decide to grant asylum, the right of visiting, or hospitality'. ${ }^{33}$ Derrida acknowledges that this process of selection is inevitable in a bordered world of sovereign states, but maintains that it contradicts the ethical and singular 'law' of 'absolute hospitality', which

\footnotetext{
${ }^{31}$ Pflüger, Vom Dialog zur Dialogizität, p. 27.

32 Published translation supplemented by author with addition of 'You don't believe that they are my cousins? I have witnesses'.

${ }^{33}$ Derrida and Dufourmentelle, Of Hospitality, p. 55
} 
requires that I open up my home and that I give not only the foreigner (provided with a family name, with the social status of being a foreigner, etc.), but to the absolute, unknown, anonymous other, and that I give place to them, that I let them come, that I let them arrive, and take place in the place I offer them, without asking of them either reciprocity (entering into a pact) or even their names. ${ }^{34}$

Far from what Kwame Anthony Appiah terms a 'cosmopolitan openness', in which 'the other' is welcomed as a fellow human being in need, ${ }^{35}$ Jelinek presents a situation where questioning extends well beyond the asking of names. Although we do not read the questions asked, the responses given in the play text create the impression that the questioning is unreasonable, repetitive and invasive. 'Sie können es sehen' [You can see it], the refugee voices repeat, in apparent response to requests for evidence that members of their family have been killed. This is an act of violence in Derridean terms: forcing them to recount and thereby relive traumatic experiences before they are deemed worthy of hospitality.

The use of unanswered questions further underlines the breakdown of dialogue: 'Don't you understand?' 'Isn't that horrifying?' 'You don't believe that they are my cousins?' (Charges 5-6). Through these questions the refugee voices attempt to elicit a response from somewhere and someone, be it the authorities, the politicians, the wider population, or, indeed, the readers or audience. By using an unidentified 'Sie', which applies to both a singular and a plural 'you', the voices directly address both the individuals

34 Derrida, On Cosmopolitanism, pp. 25-27.

${ }^{35}$ Kwame Anthony Appiah, Cosmopolitanism: Ethics in a World of Strangers (London, 2006), xv. 
processing their asylum claims and determining their fate, and the wider population of Austria and the EU which allows this to happen. They also address us as readers and audience members - the text, in which dialogue is missing on page and stage, opens up the possibility of dialogue with those reading or watching the play. We are thereby encouraged to think about how we might respond as well as how we might be accused of collusion in the system faced by those seeking refuge in our 'home' country by doing little or nothing ourselves to speak up for or at least listen to them. The frustration in the refugee voices is palpable and the postdramatic form of the text, with its unidentified and unidentifiable speakers, constantly shifting perspectives, repetitions, lack of stage directions and even basic textual markers such as punctuation, transfers some of that frustration on to us. Here, as elsewhere in the play, we too are frustrated by the lack of dialogue.

The Blitz-Eingebürgerten stand in stark contrast to the participants in the Refugee Protest Camp and the wider population of migrants and refugees they represent. Tatyana Yumasheva's route to Austrian citizenship - and therefore permanent residency - was expedited by a business deal between the Austro-Canadian automotive parts manufacturer Magna and the Russian Sberbank in an attempt to buy Opel from General Motors. The founder of Magna, Frank Stronach, later became more directly involved in Austrian politics, founding his own right-wing party 'Team Stronach für Österreich' in 2012 - notably the year of the Refugee Protest Camp Vienna. Yumasheva's citizenship was, therefore, effectively bought as part of a deal bearing striking resemblance to the 'golden passports' schemes receiving renewed critical media attention at the time of writing in Autumn 2018. ${ }^{36}$ This fact

36 Juliette Garside and Hilary Osborne, 'Golden Passports threaten European Security, warns EU Commissioner', The Guardian, 16 October 2018, 
is emphasized through rapid repetition of the nouns 'Zahlungsmittel' [currency] and 'Zahlungen' [payments] and forms of the verb 'zahlen' [to pay] in the play text (Sb 19-20). The refugees interned in Traiskirchen and involved in the Refugee Protest Camp Vienna, as well as the hundreds of thousands who subsequently followed them to Europe, have no means by which to pay for citizenship or even residency. Their lack of means relegates them to the margins of society and leaves them frustrated in their attempts to request even the basics of hospitality: 'ich aber verlange noch was, flehend zu Ihnen gewandt, ein bißchen Gewand, Essen, Wasser, einen Platz' ( $S b$ 9) [but I am still asking, turned to you suppliantly, some clothes, a bit of food, water, a place] (Charges 11). In stark contrast, Tatyana Yumasheva's perceived political and economic importance means not only that her own voice is heard, but she has many other voices speaking for her and helping her to circumvent the normally long and complicated process of applying for citizenship: 'die hat sich Zahlungen leisten können, und wenn nicht sie, dann jemand andrer für sie' ( $S b$ 19) [she made all the payments, and if not herself, then someone else did it for her] (Charges 26).

The second 'Blitz-Eingebürgerte' is also granted Austrian citizenship on the grounds of a powerful voice, but her capital is cultural rather than economic. While the refugee voices remain unheard, ignored, even actively silenced, and with little chance of being granted asylum, the beautiful singing voice of world renowned opera singer Anna Netrebko is her ticket to (or payment for) a coveted Austrian passport:

Für einen abgerundeten Klangkörper wie den dieser anderen Tochter braucht es viele Stimmen, aber nur eine Summe, und die wurde wiederum beglichen mit ihrer

https://www.the guardian.com/w orld/2018/oct/16/golden-passports-threaten-europeansecurity-warns-eu-commissioner [accessed 20 January 2019]. 
Stimme; wir wollen doch alle miteinander harmonisch klingen, ja, alle, nicht wahr, und dafür brauchen wir nicht nur unsere Stimmen, die wir sowieso nicht haben, sondern die Stimme dieser zweiten Tochter, ja, genau die, die von weither kommt ( $\mathrm{Sb}$ 21).

[a well-rounded body of sound, as that of the other daughter takes a lot of voices but only one invoice, and that in turn was covered by her voice, we all want to sound harmonious, don't we, and for that voice we need a lot of voices, which we don't have anyway, but also the voice of this second daughter, yes, her, who comes from far away] (Charges 27).

Playing on the multiple meanings and uses of the word 'Stimme' [voice], Jelinek is again able to highlight the selective hospitality of the Austrian state and the EU, in which certain voices are actively embraced as contributing to social harmony, while others are perceived to be out of tune with the 'well-rounded body of sound' and are therefore excluded or silenced. Like Yumasheva, Netrebko is able to 'pay' her way into Austria: she brings both economic and cultural capital and so is a 'desirable' migrant for whom many voices speak. In contrast, the refugee chorus of the play is without a voice of its own and without voices of support. '[D]enn von uns kehrtet ihr euer Antlitz, trotz unseres Flehens kehrtet ihr euer Antlitz ab' ( $S b$ 4) [you turned your backs on us, despite our supplications you turned your backs on us] (Charges 5), the refugee voices accuse those who are neither listening to nor looking at them. The use of the second person plural 'ihr' both indicates a shift in register - less polite and respectful but also more personal and familiar. Jelinek's employment of the word 'Antlitz' 'face' - speaks to Emmanuel Levinas' ethics in which our encounter with the 'face', or indeed 'whole human body', of the 'Other' obliges us to 'serve' that 'Other': 
I analyse the inter-human relationship as if, in proximity with the Other - beyond the image I myself make of the other man - his face, the expressive in the Other (and the whole human body is in this sense more or less face) were what ordains me to serve him. I employ this extreme formulation. The face orders and ordains me. ${ }^{37}$

This fundamental and unquestioning obligation to the face and body of the other - 'the saying is a way of greeting the Other, but to greet the Other is already to answer for him' ${ }^{38}$ - is also present in Derrida's law of unconditional hospitality which is enacted without even asking the 'Other' his name. ${ }^{39}$

The injustice of an asylum system in which we turn away from those in need but turn to face and serve those who might bring economic, political or cultural advantage to the country is clear: 'diese Töchter müssen nichts vorweisen, weil sie etwas vorzuweisen haben, die beiden, ja, die eine Geld, die andere Stimme, ihre wunderbare Stimme' ( $S b$ 22) [those daughters don't have to show any papers, because they have something to show, those two, yes, money the one, voice the other, her wonderful voice] (Charges 21). While the daughters of Danaus in Aeschylus' The Suppliants / The Suppliant Women are beneficiaries of the Ancient Greek ethos of hospitality designed to protect those in genuine need, the Russian daughters here are 'protected' only because of their perceived benefit to Austria. As Simon Hagemann argues, 'der ökonomische und machtpolitische Faktor der Grenz- und Einbürgerungspolitik wird so von Jelinek mehr als deutlich gemacht' [Jelinek thereby makes

\footnotetext{
${ }^{37}$ Emmanuel Levinas, Ethics and Infinity, trans. by R.A. Cohen (Pittsburgh, PA, 1985), p. 97. ${ }^{38}$ Ibid., p. 88

${ }^{39}$ Derrida, On Cosmopolitanism, p. 25
} 
the economic and power political factor of border and immigration policy more than clear]. ${ }^{40}$ Both are cases of conditional hospitality based on perceived mutual gain (Derrida's 'pact'), which, according to Mireille Rosello, might not even be considered hospitality at all: 'if a nation invites immigrants because they are valuable assets, because it needs them for an economic or demographic purpose, that country is not being hospitable. ${ }^{41}$ Not only are Yumasheva and Netrebko individuals 'provided with a family name, with the social status of being a foreigner' while the refugees constitute 'the absolute, unknown, anonymous other' ${ }^{42}$ but they have the ear of the authorities, the media and the wider population while the refugees ‘kein Gehör finden können’ [cannot find an ear]. ${ }^{43}$ ‘[N]iemand nimmt uns auf, das ist unerhört! Und unerhört bleiben auch wir' ( $S b$ 4) ['no one will accept us. It is unheard of! And unheard is what we are'] (Charges 4), the refugee voices lament. Furthermore, both Yumasheva and Netrebko have so many people willing to speak for them that we do not hear directly from them in the play text. Instead, we read reports of their status mediated through the refugee voices. This might be read as an example of the 'mimicking' of other voices, stories and perspectives identified by Reitani: the fact that the refugees' voices speak of the hospitality shown to others only serves to stress the inhospitality shown to them.

${ }^{40}$ Simon Hagemann, 'Performing Lampedusa. Über europäische Grenz- und Migrationspolitik in Elfriede Jelineks Die Schutzbefohlenen, Hans-Werner Kroesingers FRONTex security und BBMs Po.W.E.R.', Germanica 56 (2015), 125-40, (p. 134).

${ }^{41}$ Mireille Rosello, Postcolonial Hospitality. The Immigrant as Guest (Stanford, 2001), p. 12.

42 Derrida, On Cosmopolitanism, p. 25.

${ }^{43}$ Reitani, 'Daß uns recht geschieht', p. 69. 
This contrast is further emphasized in Jelinek's references to the absence of the interpreters required to facilitate dialogue between guests and hosts when the guests have to seek hospitality in a language that is not their own:

Wir achten darauf, weder vorlaut noch zu breit noch zu ausführlich noch zu schleppend noch zu schnell noch zu langsam im Reden zu sein. Nichts davon können wir sein, wir sprechen Ihre Sprache leider nicht, wo ist der Dolmetsch?, wo ist er hin?, Sie haben uns einen versprochen, wo ist er, wo ist er denn, wo ist der Mann, der Ihnen sagt, daß wir weder zu schleppend, zu langsam, noch zu schnell reden sollen? (Sb 7)

['We are careful not to be bold or long-winded or too detailed or dull, or too fast or too slow when we talk. We must not be any of it, unfortunately, we don't speak your language, where is the interpreter? Where did he go?, you promised us one, so where is he, where is the man who tells us we should not talk too slowly or too fast?'] (Charges 8)

Without the interpreter they are doubly disadvantaged in this grossly uneven power play: not only can they not understand the language of the laws, documents and questions with which they are confronted -'wir versuchen fremde Gesetzte zu lesen' ( $S b$ 2) ['we try to read foreign laws'] (Charges 1) - but there is nobody to advise on how best to interact and negotiate with the authorities or to interpret the way in which they speak. The - here absent - interpreter occupies a position of considerable power in facilitating dialogue between guest and host, refugee and authorities. Interpreters have strong voices, which not only speak for others but can shape the direction and the outcome of a conversation. Without them, both language and cultural barriers remain and the refugee voices continue to speak in monologue. Jelinek again uses a series of unanswered questions to emphasize attempts at but ultimate exclusion from 
dialogue. The dialogic is evident in the allusions to earlier interactions or conversations: an interpreter had been promised and some sense of 'acceptable' communicative conventions (not speaking too fast, too slow, too loud) had been conveyed.

This engagement with questions of language and hospitality resonates with Derrida's concern that:

the foreigner is first of all foreign to the legal language in which the duty of hospitality is formulated, the right to asylum, its limits, norms, policing etc. He has to ask for hospitality in a language which by definition is not his own, the one imposed on him by the master of the house, the host, the king, the lord, the authorities, the nation, the State, the father etc. This personage imposes on him translation into their own language, and that's the first act of violence. ${ }^{44}$

The requirement to communicate in the language of the 'host' constitutes an 'act of violence' in that it places conditions on the hospitality offered and accentuates the existing power dynamic between those seeking refuge and those in a position to provide it: 'Wir rufen flehend in dieser Sprache, die wir nicht kennen und können, die Sie aber beherrschen wie sich selbst' ( $S b$ 3) ['we call out to you suppliantly in this language we do not know and cannot speak, which you are in perfect control of, like of yourself'] (Charges 3). Refuge or hospitality is offered only on the condition that the guest is able to understand and communicate in the - imposed - language of the host. This forms a condition that many are unlikely to fulfil and which therefore further excludes them from dialogue, leaving them

${ }^{44}$ Derrida and Dufourmentelle, Of Hospitality, pp. 15-17 
reliant on the services of interpreters. When those interpreters do not appear and communication breaks down again, hospitality is shown to be in crisis.

\section{IV}

Complementary to the monologic features of Die Schutzbefohlenen, the polyphony of the text also contributes to the sense that the Austrian and European 'refugee crisis' is really a 'crisis of hospitality' in which the very basis of our relationship with 'the other' is called into question. Competing and conflicting responses to the Refugee Protest Camp Vienna, key moments in the unfurling of the 'crisis' such as the drowning of 360 Somali refugees off the coast of Lampedusa in October 2013, ${ }^{45}$ and the fast-tracking of citizenship applications for desirable, celebrity migrants jostle for space and attention in Jelinek's fast-flowing and often overwhelming 'Textfluss' [flow of text]. ${ }^{46}$ Moreover, as is typical for a postdramatic text, they do so without indication of who is speaking or even where the speaker changes. In some instances, a narrative shift or change of voice is indicated only by a change in content or theme as the textual indicators of narrative perspective, such as personal pronouns, remain the same. Here, in one of many examples, the first person perspective shifts from the refugee chorus and individual refugee voices to members of the Austrian population articulating their fears and prejudices. An individual (first person singular 'ich' [I]) expresses his or her

\footnotetext{
${ }^{45}$ Bernhard Schinwald, 'Tragödie ohne Folgen', Wiener Zeitung, 2 April 2014, $<$ https://www.wienerzeitung.at/nachrichten/europa/europaeische_union/619735_Tragoedie$\underline{\text { ohne-Folgen.html> }}$ [accessed 13 December 2018]. ${ }^{46}$ Felber and Kovacs, 'Schwarm und Schwelle', p. 8.
} 
concern that treating 'foreigners' as 'equals' actually means that they will be allowed to 'jump the queue' and will be given something that should, 'by rights', be 'theirs' as an Austrian citizen: 'gebietet es dem Staat, Personen, die sich in derselben Situation befinden, auch gleich zu behandeln, so, und wieso hat der jetzt, dieser Ausländer, in der U-Bahn einen Sitzplatz und ich nicht, wieso ist der früher eingestiegen als ich?, der sollte doch immer nur aussteigen!' ( $S b$ 13) [request that the State treat people who are in the same situation the same way!, okay, then why did that one, that foreigner get a seat in the subway and I didn't, how come he got in sooner than I? he should always only get out!] (Charges 17).

Just as the refugee perspective is indicated by both singular and plural first person pronouns, the singular 'ich' $[\mathrm{I}]$ here is representative of a wider 'wir' [we], of a general concern, fear, prejudice. Notable again too are the repeated questions which go unanswered. It is not only the voices of migrants and refugees that appear to be unheard or unanswered in the text, but also the voices of 'ordinary' members of the host community who feel similarly 'aus dem Gesellschaftsvertrag ausgeschlossen' [excluded from the social contract]. ${ }^{47}$ This is not to legitimize inhospitable and even xenophobic views - and Jelinek does not do this either - but to suggest that in Die Schutzbefohlenen the sense that dialogue has broken down and crisis has ensued affects many different groups, and even, as Felber suggests, blurs the differences or 'unmakes the boundaries' between them. ${ }^{48}$ Following Marschall's point that the discourse of crisis is problematic because it perpetuates the binary between us and them and reinforces boundaries between inside and outside, ${ }^{49}$ it might be argued that the refusal to label speakers and positions in Die Schutzbefohlenen constitutes a radical textual intervention

\footnotetext{
${ }^{47}$ Reitani, 'Daß uns recht geschieht', p. 64.

${ }^{48}$ Felber, '(Un)making Boundaries'.

${ }^{49}$ Marschall, 'What can Theatre do about the Refugee Crisis?', p. 153.
} 
in this discourse. We have to be attentive readers to follow the shifts in content or tone which indicate a change of speaker or voice in the text and this encourages us to rethink the ways in which we might distinguish ourselves from others.

In other instances competing narratives are articulated by the refugee voices reporting the questions they have been asked, the orders they have been given or the accusations that have been thrown at them by Austrians:

Aus unseren anspruchslosen Augen werden wir sanftmütig schauen und um eine Decke und etwas zu essen bitten, sehen Sie, werden Sie Stellvertreter von Stellvertretern, die aber auch alle nicht hier stehen, die vertreten sich woanders, sagen: Ihre Augen sind ja gar nicht anspruchslos, auch wenn Sie das behaupten, Sie stellen ja doch Ansprüche! Heute wollen Sie Decken, Wasser und Essen, was werden Sie morgen verlangen? Unsere Frauen, unsere Kinder, unsere Berufe, unsere Häuser, unsere Wohnungen? ( $S b$ 6)

['Through our unassuming eyes we will look at you softly and ask for a blanket, for food; now look, your reps' representatives will say: Your eyes are not unassuming at all, even though you say so they assume certain things - that you deserve blankets, water and food, what will you think you deserve tomorrow? Our wives, our children, our jobs, our homes?'] (Charges 8)

Here we see a shift from the modest request made by the refugees for a blanket and something to eat - the basics of hospitality - to the accusation voiced by populist politicians (representatives of the people - 'Stellvertreter von Stellvertretern') and their supporters that this is only the beginning of an endless list of demands, and the typically xenophobic claim 
that foreigners will rob them of their wives, children, jobs and homes. This is, however, reported speech, indicated by the use of the verb 'sagen' followed by the colon separating the words of the refugees from the words of the 'Stellvertretern von Stellvertretern' - 'you say: ...'. Within the reported speech, the tables turn and the second person 'Sie' now refers to the refugees while the first person 'wir' / 'unsere' refers to members of the host society. Here, as in other places in the text, the use of both first and second person pronouns indicates a form of exchange between different groups, a form of dialogicity. However, the use of reported speech - 'we say, you say' - means that in place of interaction we again see the refugee voices reporting or mimicking the voices and views of the host society. ${ }^{50}$

\section{$\mathrm{V}$}

The mimicry or performance of other voices and perspectives in place of conventional dialogue is but one thread in Jelinek's deftly interwoven tapestry of the polyphonic, dialogic and monologic that is Die Schutzbefohlenen. Although dialogic in its inclusion of multiple voices and perspectives, Jelinek's text depicts these different voices as struggling to make themselves heard and to engage with each other; they remain 'in ihren Reden befangen' [imprisoned in their own speeches]. ${ }^{51} \mathrm{I}$ have therefore argued that, despite Jelinek's resistance to 'traditional' dramatic categorisations, Die Schutzbefohlenen can be read as a postdramatic text that is monologic in quite specific ways - even where it represents a range of perspectives. Building on existing analyses of Jelinek's critical engagement with questions

50 Reitani, 'Daß uns recht geschieht', p. 64.

${ }^{51}$ Pflüger, Vom Dialog zur Dialogizität, pp. 22-23 (see footnote 10). 
of hospitality and the polyphony of the text, I have demonstrated the importance of analysing moments in the play where dialogue is attempted but fails or where voices talk past each other for furthering our understanding of Jelinek's take on the so-called 'refugee crisis'. Specifically, I have shown here that the monologic aspects of the text highlight both the inhospitality experienced by many seeking refuge in Austria and the EU and the sense of crisis amongst host society politicians and citizens stemming from their perception that they can neither control the arrival of refugees nor the discourse surrounding them. In sum, Jelinek's signature combination of polyphony, dialogicity and monologicity constitutes an effective formal critique of the 'refugee crisis' as a 'crisis of hospitality'. 